\title{
DETERMINATION OF THE COMPLEX OF CELL WALL SUBSTANCES IN PLANT PRODUCTS
}

\author{
L. Paloheimo and K. A: Vainio \\ Department of Animal Husbandry, University of Helsinki
}

Received September 30, 1965

In this department Paloheimo and Paloheimo (7) have developed a method for the determination of the complex of vegetable cell wall substances. The main principle of the method lies in boiling the sample with $0.05 \mathrm{~N}$ hydrochloric acid $(\mathrm{pH}$ about 1.3). The residue is extracted with ethanol-benzene and the final residue corrected for ash and protein. It was proved (7, p. 9) that in materials containing a high percentage of cell wall substances mere boiling with water gives about the same results as the boiling with $0.05 \mathrm{~N}$ acid. However, the filtration after boiling with water is tedious and as the said authors endeavoured to develop a method practicable even for starch containing materials, they preferred the boiling with acid. The acid concentration was chosen to be just sufficient for hydrolysing the starch to a filterable suspension. However, it appeared that, in spite of the very low acid concentration, a considerable amount of the cell wall substances was dissolved. For instance, of the pentosans in white clover grass about $40 \%$ was dissolved (7, p. 10) and according to PALOHEIMO ET AL. (8, p. 52) the pectins were dissolved by the $0.05 \mathrm{~N}$ acid. It was, however, supposed that the easily hydrolysable membrane substances may be digested in the alimentary canal even in animals with weak bacterial function. Thus the method proposed could be recommended for an estimation of food value and it is at any rate biologically more satisfactory than the Weende crude fibre determination or the 1-N-acid fibre determination. Nor is the method too conventional: a doubling of the acid concentration or of the boiling time has only a slight effect on the analysis results.

SALo (9) has developed a very useful and practical analysis system for the determination of carbohydrates and lignin in foods and faeces. Adding up the percentages of cellulose, neutral sugar hemicellulose, uronic acid hemicellulose, and lignin she obtains the percentage of total cell wall substances. Salo has even determined the cell wall complex according to Paloheimo and Paloheimo (10, p. 132). In a com- 
prehensive table $(10$, p. 128) it is evident that the relation between Salo's and Paloheimo's cell-wall-complex percentages differs rather widely. Only in a few cases has Paloheimo's method given higher results than that of Salo. In materials with a low cell-wall-complex the former method usually gives considerably lower results than the latter.

In the present paper we are describing a new method for the determination of the plant cell wall complex which is built upon quite a different principle to the method of Salo. However, the results obtained with these two methods are well in accordance.

\section{The principle of the new method}

The material to be analysed is first extracted by boiling it in $80 \%$ ethanol, then by boiling in absolute ethanol and finally with water in room temperature. The insoluble residue is weighed and the loss of ignition determined. The protein correction is made and, if the material contains starch, even the correction for starch. The boiling in $80 \%$ ethanol extracts the sugars, most of the organic acids and their salts, and the main part of the lipids and other substances, like chlorophyll, extractable with lipid solvents. The boiling in absolute ethanol completes the extraction of the lipids etc. The extraction with water makes the residue free from fructosane and some other cell enclosure substances which have not been extracted by ethanol. The corrected residue is called by us the complex of cell wall substances or simply the cell wall substances. In fact, plant cell walls contain also inorganic salts and $\mathrm{SiO}_{2}$ and thus the term organic cell wall substances would be more accurate.

As early as 1813 a similar principle was applied by Humphry DAvy (1, p. 116). In his book Elements of Agricultural Chemistry Davy presents a wood fibre determination in which the sample is alternately boiled in water and alcohol. No correction for ash, protein or starch was used. Evidently the method was applied only to very rough plant materials. Davy suggests that the composition of the wood fibre varies in different plants and plant organs.

\section{Details of the method}

If the material is not to be extracted in the wet stage it is dried in vacuum at $70^{\circ} \mathrm{C}$. About $2 \mathrm{~g}$ is weighed and put into a $500 \mathrm{ml}$ Erlenmeyer flask. $200 \mathrm{ml} 80 \%$ ethanol is added and the flask is boiled under reflux for 2 hours. The contents are then filtered using a Whatman No. 4 paper and a funnel heater. The residue is rinsed into the original flask, $200 \mathrm{ml} 80 \%$ ethanol is added, and the flask boiled again for 2 hours. The filtration etc. as above. Now follows the boiling with $200 \mathrm{ml}$ absolute ethanol. After the filtering the residue is washed with hot ethanol and rinsed with the same solvent into the Erlenmeyer flask. The ethanol is evaporated out of the flask on a water bath, $200 \mathrm{ml}$ destilled water is added, and the flask is shaken for 2 hours. The suspension is filtered through a Whatman No. 4 paper the dry weight of which is known. After drying, the paper with the residue is weighed and incinerated. The final magnitude of the organic residue is obtained by subtractions. For 
protein correction another residue is prepared and its $\mathrm{N}$-content determined. If the sample contains starch, the starch determination is made of a third residue. In starch determination we have used the iodine colorimetric method of PaLOHEImo $(3,4,5,6)$. In this determination the wet residue is used together with filter paper.

\section{Results and discussion}

Table 1 shows the results obtained with the new method (a) compared with those obtained with the method of Salo (b) and the $0.05 \mathrm{~N}$ acid method (c). The values $\mathrm{b}$ and $\mathrm{c}$ are taken from Salo's tables and the values a are results of our analyses made of the same samples which Salo has used. The table shows that in many cases the results $\mathrm{a}$ and $\mathrm{b}$ are very similar in spite of the difference in the principle of the methods in question. However, with the materials 2, 3 and 4, which are very rich in cell wall substances, the method of Salo (b) has given appreciably lower results

Table 1. The complex of cell wall substances in some plant materials determined with different methods. (\% of dry matter.)

1. Lichen (Cladonia rangiferina)

2. Marrow stem kale vascular bundles

3. Moss (Sphagnum recurvum)

4. Red clover, blooming, lower halves of stalks

5. Sugar beet pulp

6. Sedge (Carex gracilis)

7. Meadow grass (Poa pratensis), pasture stage

8. Red clover, blooming

9. Horsetail (Equisetum pratense)

10. Marrow stem kale, stalk rind

11. Wheat bran

12. Red clover heads

13. Fern (Dryopteris linnaeana) leaves

14. Birch leaves

15. Timothy, leave stage

16. Lucern grass

17. Aspen leaves (Populus tremula)

18. Marrow stem kale leaf blades

19. Chickweed (Stellaria media)

20. Swede leaf blades

21. Red clover leaves

22. Alder leaves (Alnus incana)

23. Sugar beet tops

24. Swedes, peeled

$\begin{array}{lcc}\text { a } & \mathrm{b} & \mathrm{c} \\ \text { The new } & \text { Salo's } & 0.05 \mathrm{~N} \text { acid } \\ \text { method } & \text { method } & \text { method }\end{array}$

81.5

76.0

80.4

69.1

71.1

67.9

74.2

66.1

59.4

67.3

64.5

57.9

57.8

54.4

48.9

46.9

43.9

43.3

43.2

42.0

38.2

37.9

36.8

34.8

32.9

32.3

31.0

29.1

28.9

24.8

22.1
60.4

66.4

58.3

52.6

50.1

49.5

44.1

41.7

46.0

48.1

41.9

36.7

40.5

38.9

34.5

31.0

35.1

36.2

33.3

26.2

28.9
37.8

52.4

45.0

38.9

32.2

25.9

20.0

29.5

28.2

23.5

30.9

26.7

24.6

21.4

21.0

18.2

16.6

15.9

15.5

10.2

than the new method (a), and it is noteworthy that they are even lower than the results obtained with the $0.05 \mathrm{~N}$ acid method (c). Evidently the said materials 
contain some cell wall substances which have escaped in the processes of method b. SALO $(9$, p. 58) points to the general untenability of the lignin determinations. Especially materials 5 and 21 have given higher results when method b has been used. This can be due to the fact that there are in plant materials uronic acid anhydrides and even other hemicellulose substances which are dissolved during the $80 \%$ ethanol and cold water extractions of the method a, while these components fall into the complex of cell wall substances when Salo's principle is followed. In the view of the authors no substance soluble in ethanol or cold water can be included among the cell wall substances. It is also worth mentioning that Salo has operated with crude lignin and therefore her lignin percentages are $1-2$ units higher than the corresponding true lignin figures.

As for the figures obtained with the $0.05 \mathrm{~N}$ acid method (c), most of them are appreciably lower than those obtained with the new method (a). If we take it that our new method gives a fairly reliable picture of the magnitude of the cell wall complex, the conclusion seems justified that many plant materials contain in their cell walls a considerable portion of substances which are converted in soluble form by $0.05 \mathrm{~N}$ hydrochloric acid. Using the figures of Table 1 it is possible to calculate this soluble fraction: $\frac{\mathrm{a}-\mathrm{c}}{\mathrm{a}} \cdot 100$. It appears that in materials 2 and 4 the percentage is only 3 but in materials 11 and 24 about 55 .

In Table 1 the materials are arranged in order of declining a-values. It appears that the order of c-values is not the same although the general tendency is similar. The exceptional c-values, such as those for the materials 5 and 11, suggest that possibly the $0.05 \mathrm{~N}$ acid method is more useful for an estimation of food values. But for the plant chemist the new method (a) must be considered as the most reliable one.

Table 2. Fractions dissolved by different extractions.

(\% of dry matter)

$$
\begin{array}{rrrr}
80 \% & \text { ethanol } & \text { absol. } & \text { cold } \\
\text { 1st extr. } & \text { 2nd extr. } & \text { ethanol } & \text { water }
\end{array}
$$

Oat shoots
Red clover, blooming
Lucern grass
Red clover leaves
Swede leaf blades
Alder leaves
Birch leaves
Dryopteris linnaeana leaves
Equisetum pratense
Swedes, pleed

$\begin{array}{lllll}45.2 & & 2.5 & 0.3 & 5.2 \\ 33.2 & & 1.7 & 0.2 & 3.8 \\ 35.3 & & 2.8 & 0.3 & 5.3 \\ 35.4 & & 2.4 & 0.4 & 6.6 \\ & 40.2 & & 0.3 & 8.6 \\ & 42.9 & & 0.3 & 2.6 \\ 36.5 & & 2.2 & 0.5 & 3.6 \\ & 33.3 & & 0.4 & 4.2 \\ 24.3 & & 2.8 & 0.4 & 8.1 \\ 67.0 & & 1.7 & 0.2 & 4.3\end{array}$

Table 2 presents some intermediary results which show that plant materials may contain rather abundant quantities of substances soluble in $80 \%$ ethanol. 
The first extraction is very efficient and the two $80 \%$ ethanol extractions together seem to leave in the sample very few substances extractable with absolute ethanol. Evidently the bulk of lipids is extracted by $80 \%$ ethanol. One can further see that the cold water extraction is absolutely necessary. The amount of the water extract varies considerably. In young timothy it was $9.8 \%$ and in chickweed $11.7 \%$ while in Cladonia rangiferina the percentage was only 0.8 .

Table 3. Ash and crude protein in different fractions, $\%$ of the fraction.

\begin{tabular}{|c|c|c|c|c|c|c|}
\hline & \multicolumn{2}{|c|}{$\begin{array}{l}\text { All ethanol } \\
\text { extract }\end{array}$} & \multicolumn{2}{|c|}{$\begin{array}{l}\text { Water } \\
\text { extract }\end{array}$} & \multicolumn{2}{|c|}{$\begin{array}{l}\text { Final } \\
\text { residue }\end{array}$} \\
\hline & Ash & Cr.prot. & Ash & Cr.prot & Ash & Cr.prot. \\
\hline Oat shoots & 11.3 & 18.2 & 56.7 & 10.5 & 5.8 & 24.6 \\
\hline Timothy, leaf stage & 11.5 & 11.6 & 12.3 & 5.0 & 2.9 & 27.7 \\
\hline Lucern grass & 18.8 & 25.5 & 36.6 & 11.4 & 4.2 & 29.4 \\
\hline Red clover, blooming & 12.7 & 11.3 & 28.0 & 9.3 & 2.8 & 17.5 \\
\hline Red clover leaves & 11.5 & 10.7 & 29.3 & 8.8 & 3.9 & 42.9 \\
\hline Red clover heads & 8.1 & 18.3 & 34.7 & 12.1 & 3.3 & 21.1 \\
\hline Sugar beet tops & 17.7 & 9.2 & 24.4 & 3.5 & 7.1 & 26.7 \\
\hline Chicken weed & 36.7 & 27.8 & 47.4 & 3.6 & 7.7 & 33.6 \\
\hline Carex gracilis & 13.7 & 14.2 & 41.4 & 9.5 & 2.5 & 18.8 \\
\hline Swedes, peeled & 5.9 & 10.0 & 20.7 & 5.6 & 3.2 & 10.8 \\
\hline Potatoes, peeled & 29.9 & 25.3 & 24.0 & 4.5 & 0.3 & 4.2 \\
\hline Sugar beet pulp & 4.3 & 15.4 & 6.7 & 4.4 & 5.0 & 15.3 \\
\hline Brewers' grains & 3.3 & 14.3 & 21.1 & 10.5 & 4.0 & 22.8 \\
\hline Wheat bran & 8.0 & 17.4 & 38.6 & 12.7 & 4.7 & 15.9 \\
\hline
\end{tabular}

Table 3 shows the ash and crude protein contents in different fractions. The water extract is in all cases, except in the potatoes, the fraction richest in ash, while the ash content in the final residue is the smallest. The latter circumstance is important because it diminishes the source of error connected with the ash correction. (It should be remembered that the ash is not an innate component in organisms or their fractions but an artificial product of analytical procedures.) The crude protein content is lowest in the water extract and highest, with a few exceptions, in the final residue. Thus the protein correction in our method is rather large and, if the coefficient used in the calculation of the crude protein content is not correct, this correction can result in an erroneous percentage of the cell wall complex. However, this risk is not very large because the residue after the extractions scarcely contains other nitrogenous substances than true protein. In calculating the crude protein we have used the conventional coefficient 6.25. Perhaps this is not the most valid one for plant true protein.

From Table 4 it appears that usually the ethanol extracts contain more than half of the total ash content. This indicates that the salts of the organic acids have been extracted mainly with $80 \%$ ethanol. In sugar beet pulp and brewers' grains, which are leavings after water extraction processes, nearly $3 / 4$ of the ash is found 
Table 4. Partition of ash and crude protein into different fractions.

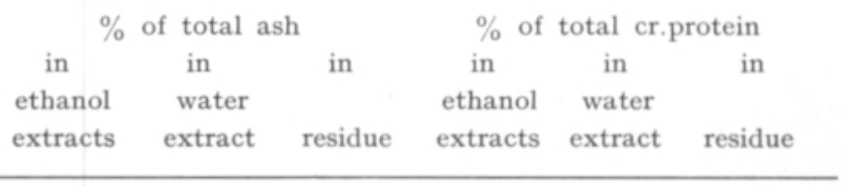

Oat shoots

Timothy, leaf stage

Lucern grass

Red clover, blooming

Red clover leaves

Red clover heads

Sugar beet tops

Chicken weed

Carex gracilis

Swedes, peeled

Potatoes, peeled

Sugar beet pulp

Brewers'grains

Wheat bran

$\begin{array}{lrrrrl}48.8 & 26.4 & 24.8 & 41.8 & 2.6 & 55.6 \\ 59.7 & 17.4 & 22.9 & 21.0 & 2.5 & 76.5 \\ 62.7 & 17.0 & 20.3 & 36.3 & 2.3 & 61.5 \\ 61.7 & 14.7 & 23.6 & 26.3 & 2.3 & 71.4 \\ 51.5 & 22.8 & 25.6 & 14.3 & 2.0 & 83.7 \\ 49.4 & 21.6 & 29.1 & 36.1 & 2.4 & 61.4 \\ 69.6 & 11.7 & 18.7 & 33.5 & 1.6 & 64.9 \\ 54.7 & 25.6 & 19.8 & 31.9 & 1.5 & 66.6 \\ 55.6 & 15.1 & 29.3 & 20.2 & 1.2 & 78.6 \\ 70.2 & 15.3 & 14.5 & 69.6 & 2.4 & 28.0 \\ 82.8 & 11.4 & 5.8 & 50.2 & 1.4 & 48.4 \\ 12.7 & 14.7 & 72.5 & 16.3 & 3.5 & 80.2 \\ 13.8 & 14.7 & 71.5 & 12.5 & 1.5 & 86.0 \\ 24.2 & 22.2 & 53.6 & 19.4 & 3.1 & 77.4\end{array}$

in the final residue. Further, the table shows that in most cases the bulk of the crude protein is retained in the residue. Swedes and potatoes which are materials poor in protein make the only exceptions. In most materials only $2-3 \%$ of the total ash is found in the water extract.

In the water extraction we have in some cases examined the effect of a longer extraction time. It appeared that a 2 hours' extraction was as efficient as a 24 hours' treatment.

Excepting the potatoes, brewers' grains, and wheat bran, the materials listed in Tables $1-4$ contain at most only traces of starch. The starch determination according to the methods of Paloheimo involves the use of a standard solution prepared of the product in question or, if wheat starch is used as standard, a knowledge of the equivalency coefficient of the type of starch in question. Such coefficients are given in the paper of Paloheimo.

The method described in this paper is not applicable to faeces analysis because of the presence of bacteria and mucin material in the final residue. However, we have developed a modification of the method which is valid for the investigation of faeces. This method will be described in this journal in the near future.

\section{$S u m m a r y$}

The authors present a new method for the determination of the complex of vegetable cell wall substances. The sample is extracted with boiling $80 \%$ ethanol, boiling absolute ethanol and cold water. The residue corrected for ash, protein, and, if necessary, for starch, gives the amount of cell wall substances. Determinations were made of the same samples of which Salo in this department, using quite a 
different principle, has determined the cell wall complex. She determined separately cellulose, neutral sugar hemicellulose, uronic acid hemicellulose, and lignin. Adding up these items Salo obtained the total of the cell wall substances. The results obtained with the new method are in most cases in agreement with the results of Salo (Table 1). The $80 \%$ ethanol seems to be a very efficient solvent. In most cases more than $35 \%$ of the dry matter of the sample was dissolved by it, while only about $0.3 \%$ was dissolved in the succeeding extraction with absolute ethanol (Table 2). 1-12\% was dissolved by water.

The new method is compared also with the earlier method of Paloheimo in which the sample is boiled in $0.05 \mathrm{~N}$ hydrochloric acid. It appeared that the results obtained with the latter procedure are considerably lower than those obtained with the new method. Evidently most plant materials contain cell wall substances which are extractable with a very weak acid treatment.

\section{REFERENCES}

(1) Davy, Sir Humphry, 1814. Elemente der Agrikultur-Chemie. German translation by Fr. Wolff. Berlin. 1-535.

(2) Honcamp, F. \& Ries, F. 1914. Untersuchungen über verschiedenen Stroharten. Landw. VersuchsStationen 84: 301 .

(3) Paloheimo, Lauri. 1930. Zur Verwendbarkeit des jodkolorimetrischen Prinzips bei Stärkebestimmungen. Bioch. Z. 222: 150.

(4) - 1948. Determination of starch according to the principle of iodine colorimetry. J. Sci. Agric. Soc. Finland 20: 109.

(5) - - \& Antrla, Irvo. 1931. Uber die Anwendung des Pulfrich-Photometers bei jodkolorimetrischen Stärkebestimmungen. Bioch. Z. 238: 401.

(6) - - \& Palohermo, IrJa. 1931. Beiträge zur Jodkolorimetrie der Stärke nach der Methode von Paloheimo, Bioch. Z.: 238: 391.

(7) - - \& Palohermo, IrJa. 1949. On the estimation of the total of vegetable membrane substances. J. Sci. Agric. Soc. Finland. 21: 1.

(8) - - VAinio, K. A., Kero, M.-L. \& Herkola, Eine. 1961. Analyses of plant products in greater detail. J. Sci. Agric. Soc. Finland 33: 51.

(9) Salo, Maija-Liisa. 1965. Determination of carbohydrate fractions in animal foods and faeces. Acta agralia fennica 105: 1-102.

(10) - 1965. On the content of cell-wall constituents in various plant materials. J. Sci Agric. Soc. Finland. 37: 127.

\section{SELOSTUS:}

SOLUSEINÄMÄAINEIDEN KOKONAISPALJOUDEN MÄÄRITTÄMINEN KASVITUOTTEISTA

L. Paloheimo ja K. A. Vainio

Yliopiston kotieläintieteen laitos, Helsinki

Kirjoittajat ovat kehittäneet uuden menetelmän soluseinämäkompleksin määrittämiseksi kasvituotteista. Vakuumissa $70^{\circ}$ :eessa kuivattua ainesta keitetään 80 -pros. etanolissa sekä sen jälkeen absol. etanolissa. Kun saatu jäännös on vielä huiskutettu huonelämpöisessä vedessä, kuivataan ja punnitaan se sekä määritetäăn hehkutuskevennys. Rinnakkaiskäsittelyllä saadusta jäännöksestä määritetäån 
raakaproteini. Jos näyte ei sisällä tärkkelystä, saadaan soluseinämäkolmpeksi vähentämällä hehkutuskevennyksestä raakaproteinin osuus. Jos taas näyte on tärkkelyspitoinen, on tärkkelys määritettävä toisella rinnakkaiskäsittelyllä saadusta jäännöksestä ja hehkutuskevennyksestä vähennettävä myös tärkkelyksen osuus. Analyysit suoritettiin samoista näytteistä, joista M.-L. Salo on aikaisemmin määrittänyt soluseinämäkompleksin aivan toisenlaista periaatetta noudattaen. Useimmissa tapauksissa uutta menetelmää käyttäen saadut tulokset ovat varsin yhtäpitäviä Salon esittämien tuloksien kanssa. Sen sijaan uudella menetelmällä saadut tulokset ovat melkoisesti suurempia kuin Paloheimon aikaisemmin esittämät 0.05-N-happomenetelmällä saadut. Ilmeisestikin kasvisolujen seinämissä, varsinkin jos ne ovat hentoja, on runsaasti aineita, jotka liukenevat hyvin laimeaankin happoliuokseen. Esimerkkeinä uudella menetelmällä saaduista tuloksista mainittakoon erăiden kasvituotteiden soluseinämäaineiden kokonaismäärät prosentteina kuiva-aineesta:

kukkivan puna-apilan varsien alaosa 66.1 sokerijuurikasleike

niittynurmikka, laidunaste

kukkiva puna-apila

vehnän lese koivun lehdet 38.2 timotei, lehtiaste 37.6 puna-apilan lehdet 29.1 sokerijuurikkaan naatit kuoritut lantut 